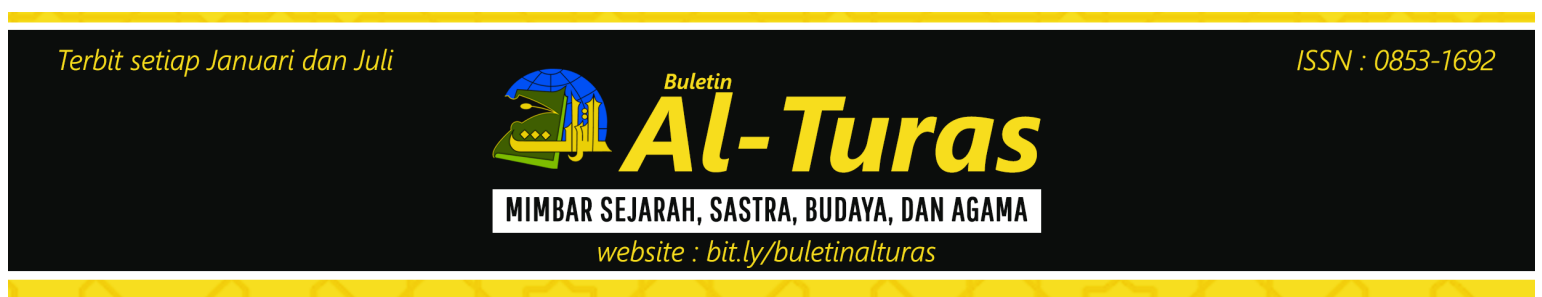

\title{
Dinamika Ekonomi Masyarakat Arab di Batavia Tahun 1900-1942
}

Akhmad Yusuf ${ }^{1}$

\begin{abstract}
Since the beginning of 17th century, Batavia which was known as Sunda Kelapa then Jayakarta then Batavia, had been a trading city which manykinds of trading activities were there. Batavia was a centre of dutch east indies government since 1619-1942. Along the colonial history, administration and statistic data of colonial government categorized their people based on their nations and, specifically, separated the Chinese and Arabs from the natives.Batavia had a strategic geography, Batavia was the best site for economic activites in Asia. Not only as a site for ships to anchor, Batavia was also functioning as one of the main port towns in Asia trading network. Depend on historical records the Chinese and Arabs kept entering the Nusantara and assimilated theirselves with the natives as 'offspring'or descendants who were born in Nusantara, however the government forced them to be separated with reason to protect the natives. Especially the traders, which the other political and economic reasons were included as well. Majority of the traders created trader cycles or networks which were consolidated within the community. Since a long time ago the Arabs left their hometowns in the dry Hadhramaut (South Yemen), including to Nusantara to make livings. They went overseas diasporically. They did trading and teaching religions to natives.
\end{abstract}

Keywords: Arabs, Hadhramaut, Networking Economy, Trade, Batavia, 1900-1942.

\section{Abstrak}

Sejak awal abad ke-17 Batavia yang dahulu dikenal dengan nama Sunda Kelapa lalu menjadi Jayakarta kemudian menjadi Batavia sudah berkembang menjadi sebuah pelabuhan dagang yang menjalankan aktivitas perniagaan. Batavia merupakan pusat kota pemerintahan Hindia Belanda sejak tahun 1619-1942. Sepanjang sejarah kolonial, administrasi dan daftar statistik pemerintah kolonial membagi-bagi penduduk menurut bangsanya dan secara khusus memisahkan masyarakat Cina dan Arab dari golongan pribumi.Batavia memiliki lokasi geografis sangat strategis, Batavia sangat cocok untuk dijadikan pusat kegiatan ekonomi di Asia. Selain sebagai tempat berkumpulnya kapal-kapal, Batavia selanjutnya juga berfungsi sebagai salah satu kota pelabuhan utama dalam jaringan perdagangan Asia. Dalam beberapa catatan sejarah bahwa golongan Arab dan Cina masuk wilayah Nusantara dan berasimilasi dengan masyarakat pribumi hingga menjadi 'peranakan' atau orang-orang keturunan yang lahir di Nusantara, namun oleh pemerintah dipaksakan dengan alasan untuk 'melindungi' kaum pribumi. Khususnya pedagang; tetapi pasti juga dengan alasan politik dan ekonomi. Kebanyakan dari para pedagang ini membentuk sebuah mata rantai atau jaringan perdagangan yang terjalin antar sesama komunitas. Sudah sejak lama masyarakatArab meninggalkan tanah air mereka di Hadhramaut (Yaman Selatan) yang tandus,untuk memperbaiki hidup.Mereka berdiaspora ke berbagai belahan dunia, termasuk ke Nusantara. Untuk berdagang dan menyebarkan agama Islam kepada penduduk setempat.

Kata Kunci : Arab, Hadhramaut, Jaringan Ekonomi, Perdagangan, Batavia, 1900-1942.

\footnotetext{
${ }^{1}$ Pusat Studi Indonesia-Arab (PSIA)
} 


\section{A. Pendahuluan}

Dari segi geografis, wilayah Asia Tenggara merupakan salah satu tempat yang strategis dalam bidang pelayaran dan perdagangan internasional. Letaknya yang strategis, karena berada di antara Samudera Hindia dan Laut Cina Selatan menyebabkan wilayah Asia Tenggara sebagai tempat persilangan sistem lalu lintas laut yang menghubungkan antara benua Timur dan Barat dengan Selat Malaka sebagai jalur penghubung utama. Hubungan dagang pun terjadi antara para pedagang Asia Tenggara dan para pedagang internasional, yang di antaranya berasal dari Cina, Arab dan India. $^{2}$

Masyarakat Arab yang bermukim di Nusantara sebagian besar berasal dari Hadhramaut, dan sebagian lagi ada yang berasal dari Muscat, tepian Teluk Persia, Yaman, Hijaz, ${ }^{3}$ Mesir atau dari Pantai Timur Afrika. Pada awalnya dari mereka jarang ada yang menetap, kalaupun ada yang menetap langsung membaur dengan masyarakat Arab dari Hadhramaut lainnya. Sebagian adalah pengembara atau petualang yang dalam waktu singkat mereka pergi lagi. ${ }^{4}$

Menurut penelitian Van den Berg, masyarakat Arab memang sudah lama hadir dan bermukim di Nusantara, sejak abad ke-17 beberapa orang sudah datang

${ }^{2}$ J.C. Van Leur, Indonesian Trade and Society: Essays in Asia Social and Economic History, terj. J.S. Holmes dan R. van Marie, (Bandung: Van Hoeve/Sumur Bandung, 1960), h. 3.

${ }^{3}$ Tampaknya di Hadramaut Hijaz biasa disebut "Syam", artinya "Suriah". Lihat LWC Van den Berg, Orang Arab di Nusantara, terj. Rahayu Hidayat, (Jakarta: Komunitas Bambu, 2010), bagian pendahuluan, h. 1.

${ }^{4}$ Dalam penelitiannya Van den Berg menyebutkan, di Singapura dan Batavia datang beberapa musafir Arab yang berasal dari sekitar Yerusalem. Mereka memeluk agama Khatolik. Lihat, Van den Berg, Orang Arab di Nusantara, h. 10. secara terpisah untuk mengadu nasib di Timur Jauh (wilayah negara-negara Asia yang jauh dari Eropa, seperti Cina, Jepang dan sekitarnya), sementara orang Hadhramaut secara massal datang ke Timur Jauh, yakni ke Nusantara pada tahun-tahun terakhir abad ke-18, ${ }^{5}$ mereka mulai banyak menetap di pulau Jawa setelah tahun 1859. Kedatangan masyarakatArab dari Hadhramaut terjadi sejak pembukaan Terusan Suez pada 1869. Pembukaan Terusan Suez ini turut memperlancar hubungan perdagangan Asia-Eropa, pembukaan Terusan Suez pun membuat pemerintah kolonial banyak melakukan impor mesinmesin dan perlengkapan modern untuk meningkatkan produksi perkebunan dan pabrik gula. Perluasan produksitanaman ekspor dan impor barang-barang dari Eropa ini kemudian mengakibatkan perdagangan internasional semakin ramai di Nusantara. ${ }^{6}$

Menurut data statistik hasil sensus khusus dan rinci yang dilaksanakan pada tahun 1885, bahwa di Jawa dan Madura tercatat jumlah penduduk keturunan Arab yang menetap di Nusantara baik orang Arab yang lahir di Arab maupun yang lahir di Nusantara sebanyak 10.888 orang. ${ }^{7}$ Hal ini disebabkan oleh eksodus besar-besaran pasca tahun 1870, di mana pelayaran dengan kapal uap antara Timur Jauh dan Arab mengalami perkembangan yang pesat sehingga memudahkan migrasi masyarakat Arab dari Hadhramaut ke Nusantara.

Sebenarnya jika kita cermati ada beberapa alasan masyarakat Arab datang

\footnotetext{
${ }^{5}$ Van den Berg,Orang Arab di Nusantara, h. 95100.

${ }^{6}$ Marwati Djoened Poesponegoro dan Nugroho Notosusanto, Sejarah Nasional Indonesia jilid IV, (Jakarta: Balai Pustaka, 1993), h. 122.

${ }^{7}$ Van den Berg, Orang Arab di Nusantara, h. 9697.
} 
ke Nusantara. Selain dengan motif untuk mencari penghidupan yang lebih layak daripada di negeri asal mereka, juga untuk berniaga dan menyebarkan agama Islam.

Dengan bertambahnya penduduk warga keturunan seperti Arab juga Cina selain Eropa, membuat masyarakat pribumi melakukan hubungan sosial perekonomian dengan masyarakat pendatang tersebut. Masyarakat Arab merupakan sebuah komunitas minoritas di Nusantara yang dikategorikan sebagai golongan Vreemde Oosterlingen atau orang Timur Jauh bersama dengan masyarakat Cina dan Timur Asing lainnya yang mana dapat dilihat dari statistik kependudukan masyarakat Arab di Nusantara.

Pada awal abad ke-19 tercatat sekitar 400 orang Arab dan Moor tinggal di Batavia. ${ }^{8}$ Jumlah orang Arab secara eksplisit baru disebutkan pada 1859 , yakni 312 orang, sebagian besar tinggal di kota dan sebagian kecil lainnya tinggal di Meester Cornelis ${ }^{9}$, Buitenzorg ${ }^{10}$, dan Tangerang. Pada tahun 1870 jumlah mereka berlipat tiga kali lebih. Selanjutnya pada tahun 1885 Batavia menampung 1.448 penduduk Arab, 972 di antaranya lahir di Hindia Belanda. ${ }^{11}$ Antara 1900-1930 minoritas Arab bertambah dari 2.245 menjadi 5.231, artinya 7 persen lebih dari keseluruhan

${ }^{8}$ Thomas Stamford Raffles, The History of Java. Jilid I, terj. Eko Prasetyanigrum, Maryati Agustin dan Idda Qoryati Mahbubah. (London: Black, Parbury and Allen, 1817), h. 63.

${ }^{9}$ Meester Cornelis sekarang merupakan sebuah daerah di Kotamadya Jakarta Timur yang bernama Jatinegara.

${ }^{10}$ Buitenzorg saat ini telah menjadi sebuah nama kota di Jawa Barat, yaitu; Kota Bogor.

${ }^{11}$ L.W.C. van den Berg, Le Hadramout et les colonies arabes dans l'archipel indien, (Batavia: Imprimerie du Gouvernement, 1886), h. 105. populasi Arab di Hindia Belanda. ${ }^{12}$ Begitu pun setelahnya dari masa 19301942 tidak begitu ada perubahan yang signifikan terhadap jumlah populasi mereka.

Mereka bermukim di kota-kota besar Nusantara seperti Surabaya, Batavia, dan Pekalongan. Keberadaan mereka kemudian dikelompokkan pada sebuah wilayah, seperti komunitas-komunitas asing lainnya. Berdasarkan dari negeri asalnya penduduk Arab di bentuk dari empat golongan yang berbeda, yaitu; Syarif, Sayid dan Habib ${ }^{13}$ merupakan kelas tertinggi yang artinya bangsawan, tinggi, ini adalah sebutan yang diberikan kepada keturunan Nabi Muhammad. Syekh dan Gabili merupakan golongan menengah. Sedangkan Masakin merupakan golongan terendah. Terdiri dari para pedagang kecil, buruh, pelayan dan budak. ${ }^{14}$ Dari pengelompokkan golongan-golongan Arab tersebut, sebenarnya yang memiliki keleluasaan dalam menjalin hubungan dengan etnis lain ialah dari kalangan Syarif, Sayid, dan Habib. Sehingga mempunyai pengaruh yang cukup kuat dalam aktivitas perdagangan di Nusantara.

${ }^{12}$ Veth, P. J. Java; Geographisch, Ethnologisch, Historisch. Jilid 4, (Harleem: Bohn, 1907), h. 20. Lihat pula, Volkstelling 1930. Jilid 7, (Batavia: Landsdrukkerij, 1935), h. 95.

${ }^{13}$ M. Hasyim Assegaf, Derita Putri-Putri Nabi Studi Historis Kafa'ah Syarifah, (Bandung: PT. Remaja Rosdakarya, 2000), h. 200-203. Lihat pula Al-Habib Alwi bin Thahir Al-Haddad, Sejarah Masuknya Islam di Timur Jauh, Terj; S. Dhiya Shahab, (Jakarta: Lentera Basritama, 1997), h. 59.

${ }^{14}$ Van den Berg, Orang Arab di Nusantara, h. 33-46. 


\section{B. Pembahasan}

\section{Lapangan Bisnis Perdagangan dan Jasa}

Sepanjang akhir abad ke-19 dan awal abad ke-20 di Hadhramaut sana, satu-satunya hasil panen pertanian yang bernilai komersial adalah tembakau Hamumi, yang tumbuh di sekitar kota Ghayl Ba Wazir dekat Shihr dan madu yang di produksi di Wadi Daw'an. Hasil panen lain yang di konsumsi di dalam negeri meliputi kurma, millet (sejenis varietas padi-padian), lucerne (sejenis rumput makanan hewan), gandum dan wijen. Beberapa jenis sayuran seperti ubi jalar, bawang merah, bawang putih, labu dan wortel tumbuh dalam jumlah kecil; serta buah mencakup jeruk nipis, pisang dan pawpaws. Sumber makanan domestik lainnya yang utama adalah ikan. Seluruh hal tersebut menjelaskan bahwa perdagangan eksternal selalu lebih berarti dalam mendukung kehidupan penduduk di wilayah itu dibandingkan produksi domestiknya. ${ }^{15}$

Atas alasan itulah pada akhirnya sebagian dari mereka berhijrah ke Asia Tenggara dalam hal ini termasuk Indonesia untuk mencoba berdagang dan mencari peruntungan lebih baik, yang tidak dapat disediakan di tanah airnya sendiri. ${ }^{16}$ Seperti halnya masyarakat Arab di Nusantara, masyarakat Arab di Batavia juga pada umumnya sebagian besar dari mereka adalah pedagang.

\footnotetext{
${ }^{15}$ W.H. Ingrams, A Report on the Social, Economic, and Political Condition of the Hadhramaut, (London: Colonial No. 123, 1937), h. 8-9 dan 50-56. Dalam Natalie Mobini Kesheh, Hadhrami Awakening; Kebangkitan Hadhrami di Indonesia, terj. Ita Mutiara dan Andri, (Jakarta: Akbar Media Eka Sarana, 2007), h. 10-11.

${ }^{16}$ Dari penyebaran kaum Hadhrami di seputar Samudera Hindia, lihat B. G. Martin, "Migration from the Hadramawt to East Africa and Indonesia, c. 1200 to 1900,"
}

Usaha mereka dilakukan dengan modal yang mungkin bisa di bilang sangat kecil. Hampir semua imigran Hadhrami bekerja dan berkembang awalnya melalui usaha perdagangan. L.W.C van den Berg mendeskripsikan pola yang khas di akhir abad ke-19, yakni pendatang baru Arab di Indonesia akan bekerja sebagai asisten toko atau pedagang kecil atas nama suatu sanak keluarga atau kenalan yang telah menjadi penduduk di daerah jajahan. Seorang Arab yang telah mendapatkan modal yang dikumpulkan sendiri secara bertahap dari gaji yang diterimanya lalu dia akan menjadi pedagang mandiri sama halnya dengan pedagang Cina. ${ }^{17}$

Sebagian masyarakat Arab ini akan hadir sebagai pedagang perantara dengan membeli barang impor dari firma Eropa yang besar dan menjualnya kembali ke pedagang lain atau konsumen Indonesia. Umumnya komoditas utama yang diperdagangkan adalah tekstil. Komoditas perdagangan lain mencakup barang manufaktur Eropa seperti jam, produk besi dan baja sedangkan komoditas dari Timur Tengah misalnya kurma, ghee, sajadah dan yang kemudian meningkat nilainya di abad ke-20 adalah buku-buku agama Islam. Apabila ia tinggal di tempat tertentu di luar pulau Jawa, kemungkinan juga dia membawa barang dagangan lokal khusus seperti produk hutan dan kuda. ${ }^{18}$

Kehidupan ekonomi mereka semakin berkembang ketika seorang Arab telah mengumpulkan modal yang

\footnotetext{
${ }^{17}$ Natalie Mobini Kesheh, Hadhrami Awakening: Kebangkitan Hadhrami.., h. 16.

${ }^{18}$ W. G. Clarence Smith, Horse Trading; The economic role of Arabs in the Lesser Sunda Islands, c. 1800-1940. Dalam Hubb de Jonge and Nico Kaptein, "Trancending Borders Arabs, politics, trade and Islam in Southeast Asia", (Leiden: KITLV Press, 2002), h. 143-158.
} 
cukup. Meskipun diperintahkan dalam Al-Qur'an untuk menentang riba, namun sebagian dari mereka hanya sebagian kecil ada yang mulai meminjamkan uang dengan tingkat bunga yang tinggi. Jika dia merupakan sebagian dari sedikit orang yang beruntung, setelah beberapa tahun bekerja keras orang Arab dapat mengembangkan kekayaan. Salah satu caranya dalam bentuk investasi properti di salah satu kota besar di Nusantara, semisal di Batavia ini. Sebagian mereka juga dapat dikatakan tuan tanah karena luas tanah yang dimilikinya. ${ }^{19}$

Seorang Arab yang memperoleh kekayaan jarang meneruskan usahanya dengan semua yang diperolehnya. Dibandingkan dengan taraf hidup masyarakat Arab yang rendah, jumlah uang yang relatif minim sudah merupakan kekayaan bagi mereka. Mereka tidak seperti masyarakat Eropa yang mendirikan rumah dagang besar dan tetap bereputasi baik meskipun para pendirinya sudah mengundurkan diri. Bahkan dalam hukum Islam sama sekali tidak mengatur perusahaan-perusahaan yang menggunakan nama kolektif dan mengenai status sosial dari rumah dagang pada umumnya.

Meskipun mengakui sejumlah
jenis asosiasi dagang, setiap menandatangani atas namanya sendiri dan bila berada dalam asosiasi, atas nama rekan usahanya. ${ }^{20}$ Ciri pribadi di dalam

${ }^{19}$ L.W.C. Van den Berg, Le Hadramout et les colonies arabes dans l'archipel indien. (Batavia: Impremerie du Gouvernement, 1886), h. 134-158.

${ }^{20}$ Pada tahun-tahun terakhir ini, dua atau tiga kali seorang notaris di Batavia membujuk klien Arabnya untuk menandatangani kontrak perusahaan, supaya mempunyai status sosial. Yang terjadi mereka, menggunakan sebuah nama untuk rekan-rekan yang berusaha bersama, misalnya "empat saudara al-Habsyi", "keluarga dari usaha itu bertentangan dengan pendirian usaha dagang yang eksistensinya legal di luar para pemiliknya. Ciri tersebut merupakan syarat utama agar sebuah rumah dagang diakui dan dapat bertahan lama.

Mengenai modal tak bergerak di dalam perdagangan yang sebenarnya, masyarakat Arab lebih suka menginvestasikan pada gedunggedung atau mereka membelinya untuk kemudian dikontrakkan. Pada wilayahwilayah Nusantara termasuk Batavia yang berada di bawah kekuasaan pemerintah Hindia Belanda, kaum Pribumi lazimnya hanya mempunyai hak memiliki warisan dalam bentuk ladang yang hanya dapat dijual kepada orang sebangsanya. Karena itu, investasi di desa hanya dapat dijual kepada orang sebangsa. Akibatnya, investasi oleh orang Arab di desa dapat dikatakan dilarang. Nilai semua gedung milik orang Arab di daerah jajahan Belanda sekitar 11 juta gulden. Di Batavia 2,5 juta, Semarang sekitar 1 juta, Surabaya sekitar 3 juta, Palembang sekitar 2,5 juta dan Pontianak kurang lebih 2 juta. Di daerah jajahan Inggris, diperkirakan gedung milik Arab mencapai 5 juta, yang 4 juta paling tidak adalah milik masyarakat Arab yang bermukim di Singapura. $^{21}$

Meskipun demikian, sebagian besar orang Arab yang memiliki bangunan tetap meminati perdagangan dan menggunakan sebagian dari modalnya untuk dipinjamkan sebagai modal kepada rekan dagangnya, orang Cina dan Pribumi. Dahulu sebelum memasuki abad ke-20 ini, mereka suka

al-Baghdadi", dan sebagainya. Tentu saja, hakikat sosialnya tetap tidak berubah.

${ }^{21}$ L.W.C van den Berg,Orang Arab di Nusantara, terj. Rahayu Hidayat, (Jakarta: Komunitas Bambu, 2010), h. 124. 
juga membeli kapal-kapal besar, namun cara investasi itu sekarang sudah kurang menguntungkan. Mereka yang masih memilikinya berusaha melepaskannya tanpa terlalu banyak merugi.

Masyarakat Arab di Nusantara, dikenal sebagai sosok pedagang dan pekerja keras. Dapat dikatakan bahwa komunitas ini merupakan salah satu pesaing kuat golongan Cina dalam menguasai pasar apapun, meski pada awal kedatangannya mereka lebih banyak berdagang rempah dan persewaan properti, namun seiring waktu banyak pula masyarakat Arab yang menekuni bidang-bidang lainnya, terutama garmen dan meubel.

Awal abad ke-19 merupakan puncak perdagangan masyarakat Arab di Nusantara, dimana mereka memiliki hubungan dagang dengan Maskat dan Mekkah. ${ }^{22}$ Tak hanya menguasai pasarpasar besar, wilayah perdagangan mereka bahkan menembus desa-desa hingga pernah mendapatkan larangan dari Pemerintah Kolonial bagi orang Arab untuk berdagang di pedesaan.

Komoditi utama dalam perdagangan Arab adalah cita katun (bazz) dan katun India (qumāsy) yang diimpor dari Eropa. Perdagangan cita itu jauh melampaui perdagangan komoditi lain yang dilakukan oleh golongan Arab. Dimana-mana terdapat perdagangan cita, sedangkan perdagangan komoditi lain hanya ada di beberapa tempat.

Komoditi yang menduduki peringkat kedua adalah berlian dan batu permata lainnya. Di Batavia, tidak kurang dari tujuh orang Arab berusaha di bidang itu. Mereka tidak memiliki toko seperti jauh hari di Eropa, mereka pun tidak menjual perhiasan, mereka hanya menjual batu ${ }^{22}$ Lihat antara lain P.J. Veth, Borneo's Westerafdeling, Jil.I, hlm.371. permata. Barang berharga itu tidak dijajakan seperti halnya cita katun dan katun India, pembeliannya pun dari golongan yang lebih terhormat atau dari golongan ekonomi kuat.

Peringkat ketiga diduduki beraneka komoditi impor dari Eropa, barangbarang dari emas dan perak, arloji, makanan yang diawetkan, barangbarang dari logam, senjata, setra, tembikar, gerendel, dan berbagai barang dari baja, besi, atau lembaga, rempahrempah, cerutu, minyak tanah dan sebagainya. Meski demikian mereka menolak untuk berjualan anggur dan minuman beralkohol yang memang dilarang dalam Islam.

Selain itu masyarakat Arab juga terkenal karena sering meribakan uang, meskipun dalam hukum Islam termasuk dosa besar, bukannya tidak populer di kalangan orang Arab di Nusantara hampir tidak ada kapitalis Arab yang belum pernah sekalipun meminjamkan uang dengan riba, meskipun itu hanya merupakan usaha pelengkap. Memang jumlah mereka yang profesinya hanya meribakan uang sangat terbatas dan sebagian besar di antaranya berusaha menutupi usaha yang tidak halal itu dengan transaksi tersamar. Memang agaknya terlihat sangat kasat mata mengenai hal itu, namun pembelian dengan hak penjual untuk membeli kembali dan penjualan barang secara kredit yang harganya setinggi langit merupakan praktik yang paling lazim. Semua transaksi tersebut diperkuat oleh perjanjian tambahan seperti kontrak penyitaan, pemotongan sebagian pinjaman sebagai jaminan, pasal pembatalan kontrak atau solidaritas dari pihak peminjam. ${ }^{23}$

\footnotetext{
${ }^{23}$ Van den Berg,Orang Arab di Nusantara, h. 125-126.
} 
Selain perdagangan, pelayaran juga bisa disebutkan sebagai salah satu sarana kehidupan masyarakat Arab. Sangat sedikit orang Arab yang menjadi kelasi, nahkoda (nawkhadsā), mualim (mu'illim) dan kerani (krānī) kapalkapal besar memang orang Arab, namun awak yang selebihnya terdiri dari pelaut Pribumi. Jarang dijumpai nahkoda Arab yang tidak menjalankan kapal rekan sebangsanya dan jarang pula kapal Arab yang dijalankan oleh nahkoda berkebangsaan lain. ${ }^{24}$

Pada sejumlah kapal Arab terdapat mualim Eropa berijazah resmi untuk memenuhi persyaratan para penyewa Eropa yang mengasuransikan kapal Arab itu. Pelaut Arab tidak pernah menjalani tujuan untuk memperoleh ijazah pelayaran dan mereka juga tidak mengasuransikan kapal mereka selama tidak dituntut oleh penyewanya. ${ }^{25}$

Usaha pelayaran itu terus maju, setelah perdagangan dan kemakmuran kaum Pribumi berkembang berkat konsolidasi dominasi Eropa. Pelayaran Arab mencapai masa gemilang antara tahun 1845-1855. Dalam periode itulah hampir semua pengusaha pelayaran memperoleh keuntungan yang sangat besar, namun setelah itu mulai mundur karena perkembangan pelayaran dengan kapal api di Nusantara yang menjadi pesaing tak sebanding bagi pelayaran dengan kapal layar. Pelayaran dengan kapal api dikuasai oleh Eropa. Baru tahun-tahun terakhir abad ke-19 orang

${ }^{24}$ Pada tahun 1885 , hanya ada satu kapal yang dimiliki orang Eropa, satu lagi milik Cina dan dua buah milik Pribumi, yang dijalankan oleh nahkoda Arab. Pada tahun yang sama, ada enam nahkoda Pribumi dan seorang Cina yang menjalankan kapal Arab.

${ }^{25}$ Diketahui bahwa kontrak asuransi dianggap umat Islam sebagai kekurangpercayaan terhadap Tuhan, lagipula hukum Islam tidak mengakuinya.
Arab dan Cina mulai turut ambil bagian, namun masih dalam skala yang sangat kecil. Kapal-kapal api Arab ini di antaranya melayani rute SingapuraJeddah khususnya mengangkut para jama'ah haji, para pemilik kapal-kapal itu memiliki agen-agen mereka di beberapa pelabuhan Nusantara yang diambil dari para pedagang Arab. ${ }^{26}$

Pertanian Arab terbatas dalam koloni-koloni di Batavia, Pontianak dan Singapura. Kecuali keturunanya yang berdarah campuran, jarang ada orang Arab yang memegang sektor ini. Sama halnya dengan aristokrat Pribumi, orang Arab di Nusantara tampaknya menganggap kerja tani tidak sesuai dengan harkat mereka. Pada Keresidenan Batavia sejumlah masyarakat Arab memiliki tanah luas yang disesuaikan oleh pemerintah khususnya pada awal abad ke-19 dengan syarat pemiliknya menjamin kepada penduduk Pribumi kepemilikan ladang, kebun dan tempat tinggal mereka secara turun-temurun. Meskipun demikian, kepemilikan turun-temurun disesuaikan dengan keuntungan pemiliknya, untuk menjadi sumber penghasilan yang utama. Pemilik Arab hampir tidak mengurusi untuk keperluannya sendiri.

Di samping tuan-tuan tanah itu, masih ada beberapa masyarakat Arab di Batavia yang memiliki kavling-kavling kecil untuk mengelola lahan pertanian tersebut atas persetujuan petani pemilik tanah dengan sistem bagi hasil. Pada umumnya, di dalam pengaturan dan pengelolaan tanah-tanah mereka, seperti juga dalam perdagangan, sikap pelit mereka selalu jadi hambatan. Hampir semua berusaha mengambil keuntungan sebesar-besarnya dari tanah mereka, tanpa berpikir untuk menjaga mutu ${ }^{26}$ Van den Berg,Orang Arab di Nusantara, h. 127-134-135. 
tanah dengan cara-cara yang ilmiah. Ketakutan akan pengeluaran sesaat membuat mereka buta bahwa tanahnya memberikan bunga sesuai apa yang dipinjamkannya. Maka tanah-tanah orang Arab pada umumnya memberi kesan kurang subur. ${ }^{27}$ Berikut ini adalah gambaran penghasilan dari sektor pertanian di Nusantara pada tahun 1926.

Pengahasilan Pertanian, $1926^{28}$

\begin{tabular}{|c|c|c|}
\hline Kelas & $\begin{array}{c}\text { Persen } \\
\text { rakyat }\end{array}$ & $\begin{array}{c}\text { Penghasilan } \\
\text { (f.) }\end{array}$ \\
\hline Pemilik & & \\
tanah: & 2,5 & $1.090,49$ \\
Kaya & 19,8 & 299,83 \\
Biasa & 27,1 & 147,65 \\
Miskin & 3,4 & 118,75 \\
Penyewa & 12,4 & 101,36 \\
Buruh & 19,6 & 120,32 \\
Tani & & \\
\hline
\end{tabular}

Meijer Ranneft, Belastingdruk, hal. 10.

Profesi pengrajin yang sebenarnya hampir tidak masuk hitungan. Pekerjaan itu hampir seluruhnya digeluti oleh masyarakat Arab campuran. Di sekitar Batavia, terdapat sebuah lembaga litografi milik sayid Ușman bin Abd Allah bin Yahya. Di Palembang, sayid yang lain memiliki sebuah percetakan. Kemudian, di Nusantara ada lima ahli jam, tiga pengrajin perak, empat tukang kayu, seorang tukang jahit, seorang pembuat limun dan seorang masinis di kapal api milik pemerintah di kerajaan landak (pantai barat Borneo) beberapa Arab campuran berprofesi pencari intan. Dari Pasuruan, Bangil, Buleleng (Bali) dan Aceh dilaporkan bahwa beberapa Arab campuran bahkan menjadi penggotong mayat. Di dekat Batavia

${ }^{27}$ Van den Berg, Orang Arab di Nusantara, h. 135-137.

${ }^{28}$ J.S. Furnivall, Hindia Belanda Studi tentang Ekonomi Majemuk, terj. Samsudin Berlian, (Jakarta: Freedom Institute, 2009), hal. 422. seorang Arab kelahiran Hadhramaut memiliki pabrik bata (mîfā) yang cukup besar dan dua atau tiga orang Arab campuran memiliki pabrik batik. Terakhir, di Bangil, seorang Arab campuran menjadi tukang pijit.

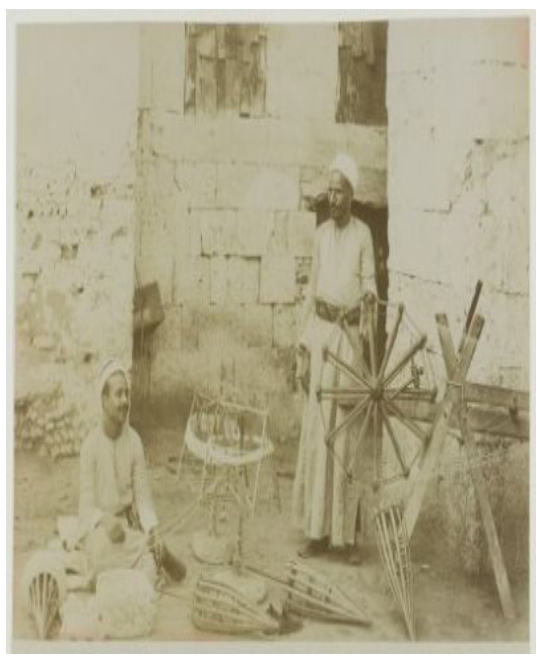

\section{Kegiatan menenun benang orang} $\operatorname{Arab}^{29}$

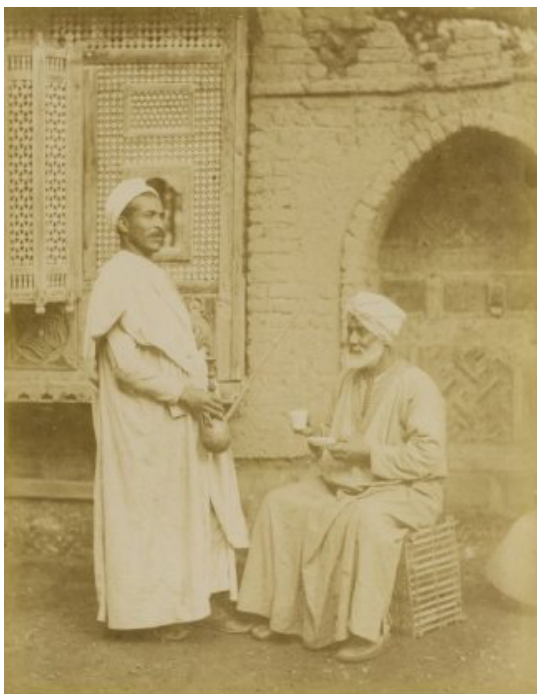

Aktivitas orang Arab ${ }^{30}$

${ }^{29} \mathrm{http}: / /$ media-kitlv.nl/all-media/indeling/ detail/form/advanced/start/2?q_search beschrijving=arabieren\&q facet beginjaar=1900-1942diakses pada tanggal : 24 Desember 2014.

${ }^{30} \mathrm{http}: / /$ media-kitlv.nl/all-media/indeling/ detail/form/advanced/start/6?q_search beschrijving=arabieren\&q facet beginjaar=1900-1942diakses pada tanggal : 24 Desember 2014. 
2. Relasi Bisnis : Pemerintah Kolonial, Tionghoa, dan Pribumi

Golongan etnis Cina sering kali diidentikkan sebagai golongan yang mempunyai peranan penting dalam perekonomian di Indonesia. Hal ini tidak dapat dipisahkan dari adanya kenyataan bahwa mereka telah mulai merintis usaha-usaha di bidang perekonomian sejak dahulu dan keberhasilan mereka ditunjang oleh banyak faktor. Faktorfaktor tersebut berasal dari berbagai pihak, baik pihak mereka sendiri, pihak pemerintah Hindia Belanda maupun dari pihak pribumi Indonesia. ${ }^{31}$

Menurut beberapa ahli, golongan etnis Cina Peranakan mempunyai satu karakter tersendiri. Skinner misalnya berpendapat bahwa ada satu karakter yang menonjol dari etnis Cina Peranakan yaitu mereka menekankan sistem nilai yang mementingkan kerajinan, kehematan, pengandalan pada diri sendiri, semangat berusaha dan keterampilan. Ada dua istilah golongan Cina di Indonesia, menurut Charles K. Coppel dan Leo Suryadinata. Pertama istilah Cina Peranakan termasuk dalam pengertian keturunan campuran ras, digunakan untuk menunjukkan perbedaan yang kontras dengan Cina Totok yang memiliki darah Cina murni. Kedua istilah Peranakan dipakai untuk membedakan orang Cina kelahiran Indonesia dari Totok yang lahir di negeri Cina dan istilah ini juga untuk menunjukkan imigran Cina yang khusus berkembang di Pulau Jawa. Ketiga istilah Peranakan untuk menunjukkan masyrakat dan kebudayaan Cina yang berkembang di antara imigran-imigran baru yang telah dipengaruhi oleh

\footnotetext{
${ }^{31}$ Seminar Sejarah Nasional IV, Sub Tema DinamikaPertumbuhan Ekonomi Bangsa Indonesia. (Jakarta: DEPDIKBUD Direktorat Sejarah dan Nilai Tradisional, 1991), h. 192-193.
}

nasionalisme abad ke-20 yang menarik perhatian sejumlah besar masyarakat Cina kelahiran Indonesia ${ }^{32}$.

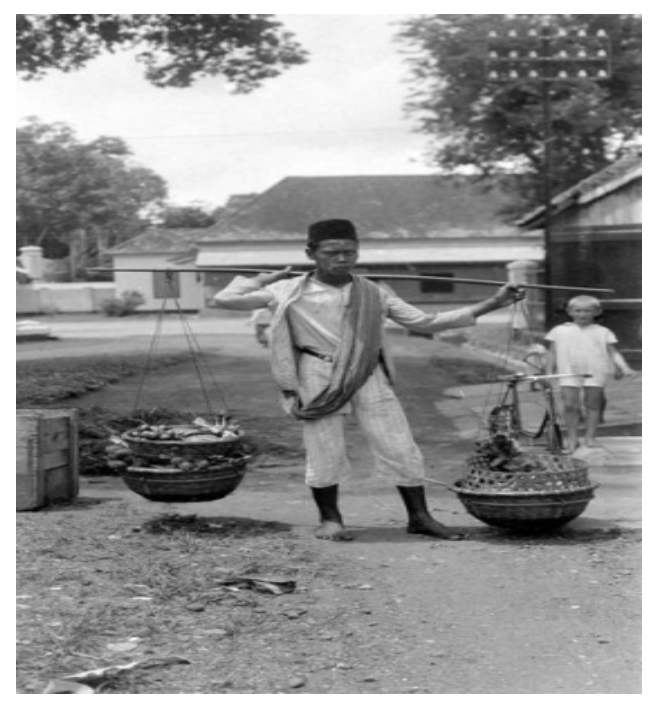

\section{Pedagang Buah di Perumahan Eropa Batavia Tahun 1930 $^{33}$}

Berbeda dengan Skinner, Mely G. Tan membedakan antara Cina Peranakan dan Cina Totok dalam bidang pemilihan bidang pekerjaan yang ternyata pemilihan itu mencerminkan perbedaan yang mencolok dalam orientasi nilai. Kalangan Cina Totok lebih menghargai kekayaan, kehematan, kerja, kepercayaan pada diri sendiri dan keberanian daripada kaum peranakan yang lebih menghargai penikmatan hidup, waktu senggang, kedudukan sosial dan perasaan terjamin. ${ }^{34}$ Karakter yang menonjol ini agaknya terbentuk dari perantauan, situasi yang merekan hadapi di perantauan mengakibatkan mereka harus mengambil sikap agar bisa bertahan.

\footnotetext{
${ }^{32}$ Coppel dan Leo Suryadinata, "An Historical Survey" dalam majalah Far Eastern History, No. 2, September 1970.

${ }^{33}$ Koleksi: Tropenmuseum TMnr_10002643 http://phesolo.wordpress.comdiakses pada tanggal : 24 Desember 2014.

${ }^{34}$ Mely G. Tan, (ed.), Golongan Etnis Tionghoa di Indonesia, h.11.
} 
Pusat perdagangan yang besar dari golongan Arab di Nusantara adalah Batavia, Semarang, Surabaya dan Singapura. Di tempat-tempat itulah mereka membeli barang dalam jumlah besar atau kecil komoditi impor kemudian dijual eceran di dalam toko mereka kepada pedagang Arab, Cina, atau Pribumi yang tidak memiliki kredit pada rumah dagang Eropa.

\section{Tabel Distribusi Berdasarkan Mata Pencaharian di Indonesia Pada Ta- hun $1930^{35}$}

\begin{tabular}{|c|c|c|c|c|c|c|}
\hline \multirow{2}{*}{$\begin{array}{l}\text { Mata } \\
\text { Pencaharian }\end{array}$} & \multicolumn{2}{|l|}{ Eropa } & \multicolumn{2}{|l|}{ Cina } & \multicolumn{2}{|l|}{\begin{tabular}{|l|} 
Pribumi \\
\end{tabular}} \\
\hline & Jumlah & $\%$ & Jumlah & $\%$ & \begin{tabular}{|l|} 
Jumlah \\
\end{tabular} & $\%$ \\
\hline $\begin{array}{l}\text { Produksi } \\
\text { Bahan } \\
\text { Mentah }\end{array}$ & 18.800 & 22,03 & 144.488 & 30,83 & 14.193 .158 & 69,99 \\
\hline Industri & 4.676 & 5,48 & 93.988 & 20,00 & 2.105 .129 & 10,38 \\
\hline Transportasi & 10.985 & 12,88 & 12,754 & 2,72 & 290.740 & 1.43 \\
\hline Perdagangan & 11.415 & 13,38 & 171.979 & 36,60 & 1.090 .868 & 5,33 \\
\hline Swasta & 11.290 & 13,23 & 7.161 & 1,52 & 150.227 & 0,74 \\
\hline $\begin{array}{l}\text { Pegawai } \\
\text { Negeri }\end{array}$ & 20.731 & 24,30 & 3,039 & 0,65 & 491.911 & 2,43 \\
\hline Lain-lain & 7.424 & 8,70 & 36.126 & 7,68 & 1.957 .609 & 9,65 \\
\hline Jumlah & 85.321 & 100,00 & 469.935 & 100,00 & 20.279 .642 & 100,00 \\
\hline
\end{tabular}

Data sensus penduduk tahun 1930 menunjukkan bahwa 57,7 persen orang Cina hidup dari perdagangan dan 20,8 persen berkecimpung di dunia industri. Sedangkan 72,7 persen orang Arab bermata pencaharian dari berdagang dan hanya 10,6 persen yang hidup di sektor industri. ${ }^{36}$ Walaupun mempunyai karakteristik serta latar belakang yang berbeda, mereka bisa disebut sebagai "minoritas pedagang" (trading minorities) atau "minoritas perantara" (middlemen minorities). ${ }^{37}$

${ }^{35}$ Sumber: Leo Suryadinata, op.cit., h. 78.Lihat juga: Seminar Sejarah Nasional IV, Sub Tema Dinamika Pertumbuhan Ekonomi Bangsa Indonesia. (Jakarta: DEPDIKBUD Direktorat Sejarah dan Nilai Tradisional, 1991), h. 200.

${ }^{36}$ Didi Kwartanada, "Dari 'Timur Asing' ke 'Orang Indonesia': Pemuda Tionghoa dan Arab dalam Pergerakan Nasional (1900-1942)", Prisma Vol. 30, No. 2 (2011), hlm. 42-43.

${ }^{37}$ Charles A. Coppel, "Arab and Chinese Minority Groups in Java", dalam kumpulan karangannya, Studying Ethnic Chinese in Indonesia (Singapore: Singapore Society of Asian Studies, 2002), h. 98-99. Seperti di kutip Suratmin
Pola hidup pedagang Arab ini kemungkinan terpelihara dengan baik sampai abad ke-20. Catatan yang dihimpun dari periode 1912 sampai 1919 menunjukkan bahwa meskipun terjadi kekacauan yang disebabkan Perang Dunia Pertama, orang Arab baru yang datang dan mengajukan permohonan izin masuk ke Jawa berjumlah total 1.121 jiwa. Sekitar 75 persen adalah pedagang yang saat kedatangannya di Nusantara memiliki antara seratus dan seribu lima ratus gulden tunai dengan cara menjual barang (terutama yang terkenal madu Daw'an) senilai seratus sampai seribu dua ratus gulden. 18 persen lebih jauh menjamin dukungan anggota keluarga yang telah tinggal di Nusantara, melalui siapa mereka mendapat akses modal dagang hanya 7 persen yang datang tanpa modal berarti. ${ }^{38}$ Gambaran ini memperkuat dugaan bahwa pada awal abad ke-20 mayoritas imigran Arab memiliki uang atau hubungan keluarga di Nusantara.

Kontak usaha dagang bersama di antara masyarakat Arab lazimnya dilakukan secara lisan dan modal yang ditanamkan dalam setiap perusahaan selalu sangat kecil. Misalnya, modal 100.000 gulden dibagi di antara 20 sampai 30 perusahaan. Jadi mitra usahanya paling-paling penjaja keliling atau pemilik toko kecil. Tidak ada orang Arab yang mau berisiko menanamkan modal besar di dalam satu perusahaan. ${ }^{39}$

Dapat dikatakan bahwa kekurangan modal merupakan kelemahan terbesar dan Didi Kwartanada, Biografi A.R. Baswedan Membangun Bangsa dan Merajut keindonesiaan, (Jakarta: PT. Kompas Media Nusantara, 2014), h. 15.

${ }^{38}$ Directore of Justice to Governor General, 26 April, 1919, mr. 1015/19, terdapat dalam vb. 26 Juni 1919, no. 16, MK, ARA.

${ }^{39}$ Van den Berg,Orang Arab di Nusantara, h. $127-128$. 
dalam perdagangan Arab. Kelemahan itu ditambah lagi dengan mudahnya rumahrumah dagang Eropa memberikan kredit kepada siapapun yang mengenakan sorban. Saat mengenal masyarakat Arab yang sebenarnya tidak memiliki apapun, mampu setiap bulan membeli barang dagangan seharga 20.000 gulden secara kredit. Jika usahanya maju, ia mampu membayar cicilannya, namun jika mereka hanya dapat menjual barangnya dengan merugi, mereka berusaha meminta penangguhan pembayaran kredit, dengan harapan harga barang itu akan segera naik. Jika harapan itu kandas, mereka berupaya memperpanjang tunggakan, dengan membayar para kreditor yang paling mendesak dengan barang dagangan dibeli secara kredit di tempat lain. Cara seperti itu sama dengan gali lubang tutup lubang dan akan berakhir dengan pailit.

Pailit orang Arab yang cukup khas dapat diketahui bahwa di Hadhramaut tidak ada buku catatan yang teratur dan tentu saja di sana tidak dikenal rekening orang yang digunakan dalam perdagangan Eropa. Perlu pula ditambahkan bahwa perdagangan di Hadhramaut yang cukup berhasil jarang berpindah tempat, sedangkan sebagian besar orang Arab di Nusantara adalah suku, golongan menengah kecil atau Sayid, artinya orang-orang yang tidak mengenal bidang usaha. Jadi jelas mengapa perdagangan Arab ditandai oleh ketidaktahuan akan peraturan perdagangan seperti pengguna buku catatan dagang.

Menurut van den Berg di Batavia, kiranya tidak lebih dari lima atau enam orang Arab yang buku catatannya memenuhi syarat. Karena tahu apabila mengalami pailit mereka harus menunjukkan buku catatan dagang.
Mereka membuatnya sebisanya dengan bantuan catatan mereka, apabila mereka melihat bahwa kebangkrutan tak terhindarkan atau mereka hanya menyusun catatan biasa yang tidak mungkin disusun neracanya, kecuali pailitnya. Karena sembilan diantara sepuluh pengusaha yang pailit tidak mampu menyusun buku catatan dagang secara Eropa, sangat sulit bagi pengadilan untuk memutuskan apakah ada penyelewengan atau tidak. Akibatnya ancaman hukuman yang tertera di dalam kitab hukum pidana terhadap kebangkrutan, biasanya tidak berdaya guna. ${ }^{40}$

Masyarakat Arab punya tradisi bisnis di perantauannya, begitu pun dengan mereka yang ada di Batavia. Tiga bersaudara keturunan Arab dari Padang, Sumatera Barat, tiba di Batavia pada 1920-an. Semuanya pengusaha, harta mereka berlimpah hasil warisan orang tua dan berbisnis. Namun misi utama mereka di Batavia adalah bukan untuk berbisnis melainkan memperkenalkan tradisi musik dan sandiwara khas mereka kepada warga Batavia. ${ }^{41}$

Menurut Mudrik bin Shahab, Selain berjiwa bisnis, mereka Sayid Idrus, Sayid Syehan, dan Sayid Abubakar, juga berjiwa seni; senang hiburan mereka termasuk klan bin Shahab yang masih ada hubungan darah dengan Ali Menteng. ${ }^{42}$ Mereka di Batavia bisa tinggal bersama kerabat, bisa pula di luar kampung Arab. Pemerintah kolonial telah menghapus wijken stelsel dan passenstelsel pada 1919. Shahab bersaudara memilih tinggal di Sawah Besar sembari menjalankan bisnis ${ }^{40}$ Van den Beerg, Orang Arab di Nusantara, h. 128.

${ }^{41}$ Hendaru T. Hanggoro, "Berbisnis di Rantau", Historia, Nomor 15. Tahun II, 2013, h. 44.

${ }^{42}$ Hanggoro, "Berbisnis di Rantau"..., h. 44. 
di Sumatera. Mereka juga membeli sebidang tanah untuk gedung pentas, rombongan mereka tampil secara teratur dan permanen di gedung itu.

Faktor-faktor yang mendorong etnis Cina menjadi pedagang antara lain adalah adanya peraturan-peraturanyang dikeluarkan oleh pemerintah Hindia Belanda yang pada prinsipnya menghalang-halangi kontak antar masyarakat Cina dan memusatkan mereka di daerah-daerah tertentu sama halnya dengan orang Arab atau Timur Asing lainnya yang harus memiliki passen stelsel untuk bepergian keluar kota dan aturan-aturanyang memaksa untuk mereka bertempat tinggal di daerah-daerah tertentu. Dalam kenyataannya pemukiman mereka di Jawa disebut "Pecinan". Daerah pemukiman itu kemudian berkembang menjadi pusat perdagangan yang besar pengaruhnya terhadap kehidupan ekonomi pasar. ${ }^{43}$

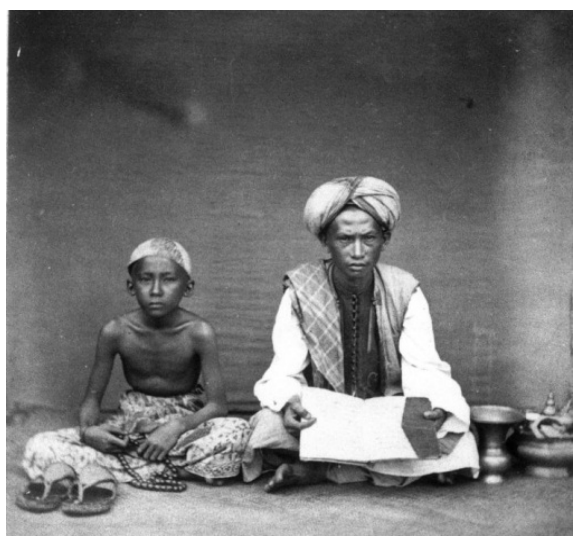

Pedagang Arab ${ }^{44}$

\footnotetext{
${ }^{43}$ Tan Giok Lan, The Chinese of Sukabumi, hal. 4-11. Dan lihat pula dalam Seminar Sejarah Nasional IV, Sub Tema DinamikaPertumbuhan Ekonomi Bangsa Indonesia. (Jakarta: DEPDIKBUD Direktorat Sejarah dan Nilai Tradisional, 1991), h. 198-199.

${ }^{44}$ COLLECTIE_TROPENMUSEUM Een_koranschool_met_leraar_en_leerling TMnr_60009392 diakses pada : 24 Desember 2014
}

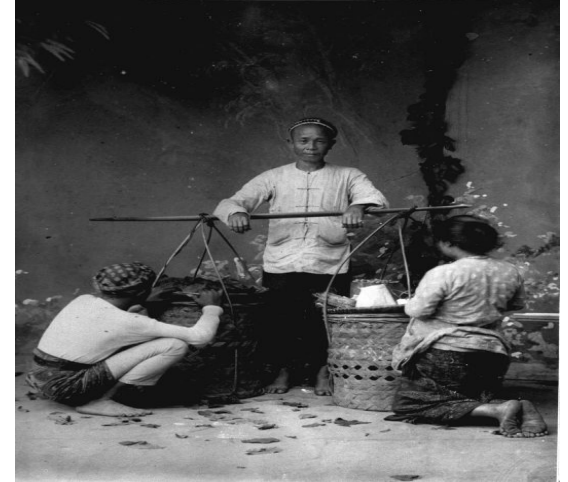

Pedagang Cina ${ }^{45}$

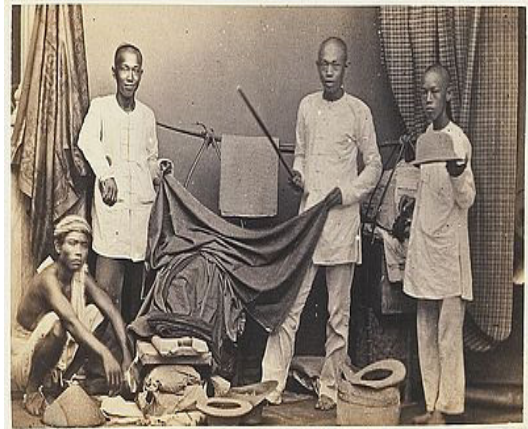

Pedagang Cina

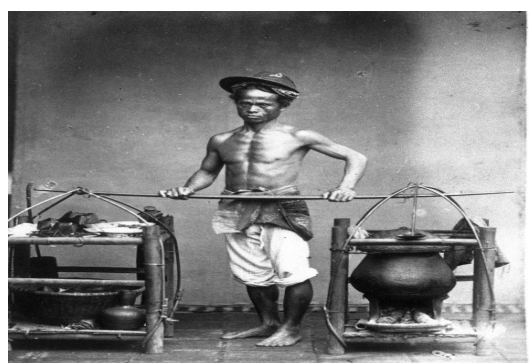

\section{Pedagang Pribumi ${ }^{46}$}

Peranan dan pengaruh pedagang Cina tak hanya terbatas di perkotaan saja tetapi juga memasuki jaringan hubungan perekonomian kota dengan desa-desa di sekitarnya. Arus barang perdagangan dari kota ke desa atau sebaliknya dapat dikatakan dikuasai oleh para pedagang perantara Cina ini. Pedagang-pedagang pasar di desa biasanya mengambil barang

\footnotetext{
${ }^{45}$ COLLECTIE TROPENMUSEUM Chinese handelaar TMnr 60012417 diakses pada : 24 Desember 2014.

${ }^{46}$ COLLECTIE TROPENMUSEUM Een man_uit_Batavia_met_pikolan_voor_het transport_van_zijn_warong_TMnr_60009385 diakses pada : 24 Desember 2014.
} 
dagangannya dari pedagang-pedagang perantara Cina di kota tersebut. Bahkan tak berarti menutup kemungkinan bagi mobilitas para pedagang Cina untuk beroperasi langsung ke pasar-pasar desa sebagai supplier jadi bukan pedagang yang langsung berhadapan langsung dengan konsumen lokal. Sebaliknya dalam arus barang perdagangan dari desa ke kota pun peranan para pedagang perantara Cina pun cukup besar untuk diperhitungkan, terutama hasil-hasil pertanian ekspor seperti tembakau, cengkeh dan lada. ${ }^{47}$

\section{Tabel Pembagian Pekerjaan Cina} Totok dan Peranakan di Jawa Tahun 1930 (dalam \%) ${ }^{48}$

\begin{tabular}{|l|l|l|}
\hline Pekerjaan & Totok & Peranakan \\
\hline $\begin{array}{l}\text { Produksi } \\
\text { bahan mentah }\end{array}$ & 1,13 & 14,87 \\
\hline Industri & 27,10 & 15,27 \\
\hline Transportasi & 0,97 & 4,16 \\
\hline Perdagangan & 65,02 & 52,41 \\
\hline Swasta & 2,43 & 1,87 \\
\hline $\begin{array}{l}\text { Pegawai } \\
\text { Negeri }\end{array}$ & 0,11 & 0,86 \\
\hline Lain-lain & 3,24 & 9,65 \\
\hline Jumlah & 100,00 & 100,00 \\
\hline
\end{tabular}

Dari tabel tersebut dapat kita lihat bahwa besarnya peranan etnis Cina dalam perekonomian waktu itu dan kuatnya posisi pedagang perantara Cina dalam struktur perekonomian yang berorientasi kepada pasar bebas atau perekonomian liberal.Dari posisi kunci ini mereka dapat memperluas jaringan kontak-kontak

perdagangannya,

${ }^{47}$ Seminar Sejarah Nasional IV, Sub Tema DinamikaPertumbuhan Ekonomi Bangsa Indonesia. (Jakarta: DEPDIKBUD Direktorat Sejarah dan Nilai Tradisional, 1991), h. 199.

${ }^{48}$ Sumber: Leo Suryadinata, Pribumi Indonesians The Chinese Minority and China, h. 80.Lihat juga: Seminar Sejarah Nasional IV, Sub Tema DinamikaPertumbuhan Ekonomi Bangsa Indonesia. (Jakarta: DEPDIKBUD Direktorat Sejarah dan Nilai Tradisional, 1991), h. 197. lebih jauh kearah peminjaman uang, perdagangan besar-besaran dan pembelian bahan-bahan pokok untuk pemasaran ekspor meskipun mereka hanya berhasil mendapat sedikit jalan kearah sektor-sektor kehidupan ekonomi yang dikuasai oleh orangorang Belanda, misalnya perkebunan, impor-ekspor, perdagangan besar dan perbank-kan sampai berakhirnya masa penjajahan. ${ }^{49}$ Golongan etnis Cina di samping pekerjaan itumampu memainkan peranannya sebagai golongan menengah dalam struktur perekonomian kolonial Belanda, dimana peranan pedagang perantara mempunyai peranan penting di dalamnya.

Pada masa itu perdagangan dapat di bagi menjadi tiga jenis yaitu, perdagangan besar yang pada umumnya dikuasai oleh perusahaan swasta Belanda, perdagangan kecil yang pada umumnya dikuasai oleh pedagang pribumi dan pedagang perantara sebagai penghubung antara perdagangan besar dan perdagangan kecil yang pada umumnya dikuasai oleh golongan Timur Asing dan pribumi.

Perdagangan besar adalah suatu cabang perdagangan yang mengurus ekspor-impor; perdagangan kecil adalah suatu cabang perdagangan yang membeli barang dagangan dari tangan kedua atau ketiga untuk kemudian dijual langsung ke tangan konsumen. Perdagangan perantara mempunyai dua fungsi, yaitu perdagangan distribusi terutama menyebarkan barang-barang konsumsi yang diimpor dari luar negeri. Perdagangan koleksi terutama berfungsi untuk mengumpulkan hasil-hasil tanaman dagang dari petani langsung atau melalui pedagang kecil untuk diteruskan kepada pedagang besar.

${ }^{49}$ Victor Purcell, The Chinese in Southeast Asia,h. 47. 
Perdagangan kecil sendiri dapat dibagi dalam dua jenis, yaitu perdagangan keliling dan perdagangan menetap. Perdagangan keliling juga dapat dibagi dalam dua bagian yaitu perdagangan kelontong yang pada umumnya dikuasai oleh pedagang Cina, dan pedagang jalanan yang pada umumnya dikuasai oleh pedagang pribumi. Perdagangan menetap dibagi tiga jenis, yaitu warung, pasar dan toko. ${ }^{50}$

Perdagangan distribusi terutama menjual barang-barang seperti tekstil, makanan dan minuman, barang-barang kelontong, beras, gula dan juga hasil produksi dalam negeri. Perdagangan koleksi terutama membeli hasil kerajinan tangan rumah tangga, hasilhasil tanaman dagang seperti kopra, kapok, singkong, jagung, beras dan kulit. Perdagangan kelontong terutama menjual barang-barang keperluan sehari-hari seperti kaca, hasil kerajinan tangan yang diimpor dari Cina, atau benang. Perdagangan jalanan terutama menjual kebutuhan pangan penduduk seperti daging atau ikan.

Pedagang-pedagang kelontong ini biasanya menjajakan barang-barang jadi dan barang-barang klontongan. Mereka tidak hanya berkeliling di kota-kota saja, tetapi sering pula ke desa-desa dan kampung-kampung untuk menawarkan barang-barangnya kepada penduduk. Terkadang mereka menyewa kuli pribumi untuk memikul barang-barang mereka dengan pikulan.

\footnotetext{
${ }^{50}$ Liem Twan Djie, De Distribueerende Tusschenhandel der Chinezen op Java, h. 4-11.
}

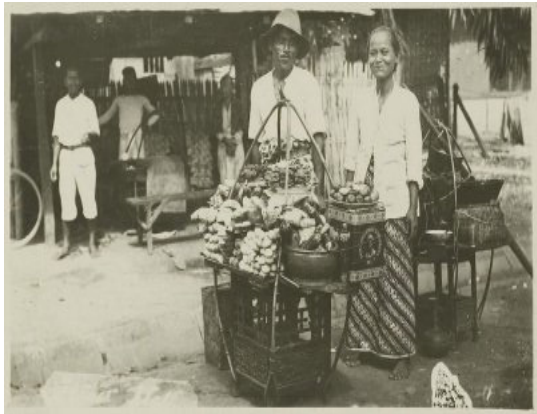

\section{Penjual makanan di Batavia ${ }^{51}$}

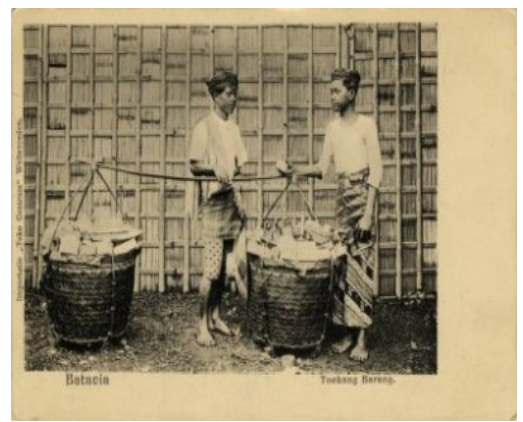

Tukang Barang ${ }^{52}$

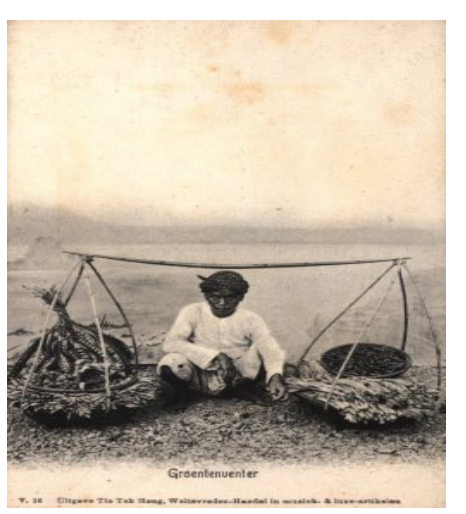

Penjual Sayuran $^{53}$

${ }^{51} \mathrm{http}: / /$ media-kitlv.nl/all-media/indeling/ detail/form/advanced/start/486?q_search beschrijving=batavia\&q facet beginjaar=1900-1942diakses pada : 26 Desember 2014.

${ }^{52} \mathrm{http}: / /$ media-kitlv.nl/all-media/indeling/ detail/form/advanced/start/75?q_search beschrijving=batavia\&q facet beginjaar $=1900-1942$ diakses pada : 26 Desember 2014.

${ }^{53} \mathrm{http}: / /$ media-kitlv.nl/all-media/indeling/ detail/form/advanced/start/102?q_search beschrijving=batavia\& q facet beginjaar=1900-1942diakses pada : 26 Desember 2014 


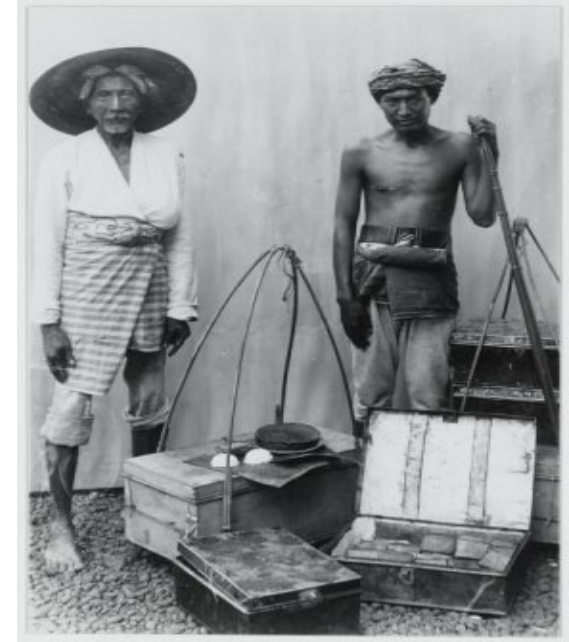

Penjual Kue ${ }^{54}$

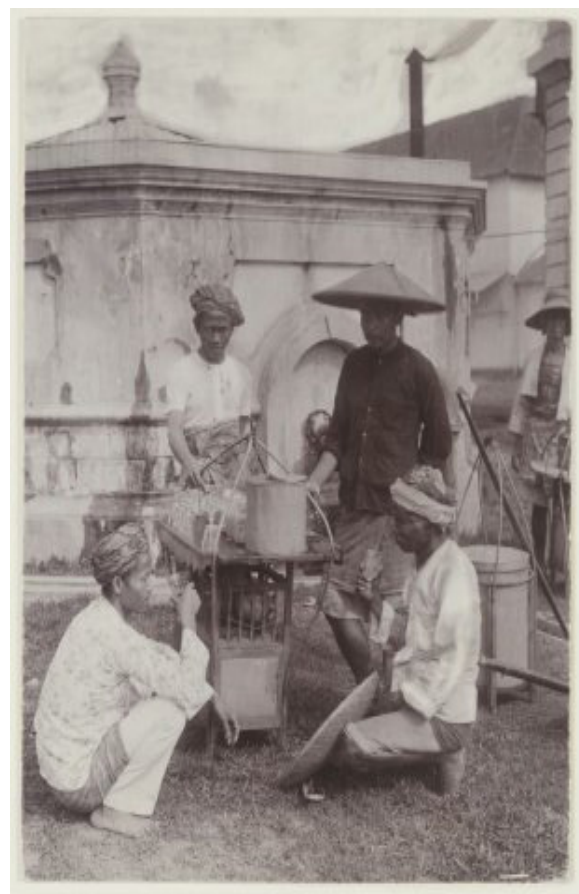

Penjual Limun ${ }^{55}$

${ }^{54} \mathrm{http}: / /$ media-kitlv.nl/all-media/indeling/ detail/form/advanced/start/787?q_search beschrijving=batavia\&q facet beginjaar=1900-1942diakses pada : 26 Desember 2014

${ }^{55}$ http://media-kitlv.nl/all-media/indeling/ detail/form/advanced/start/55?q search beschrijving=batavia\&q facet beginjaar $=1900-1942$ diakses pada : 26 Desember 2014

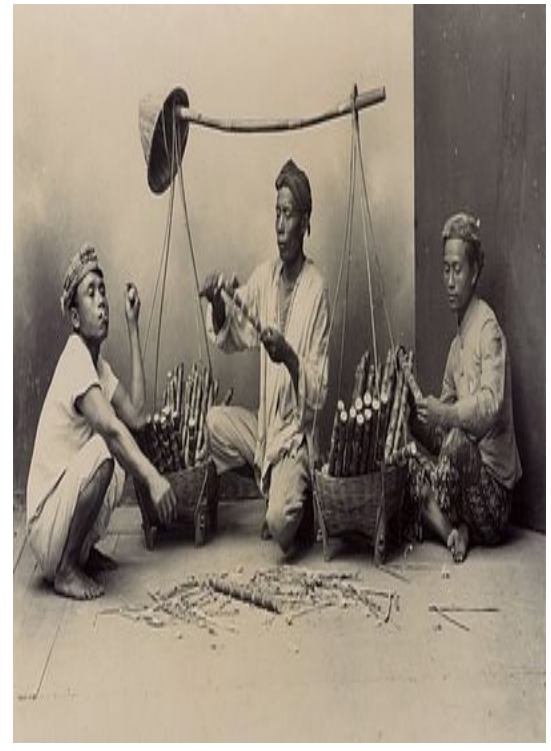

Penjual Minuman Tebu Tahun $1915^{56}$

Seperti telah disebutkan diatas perdagangan perantara pada umumnya dikuasai oleh golongan Timur Asing dan pribumi, namun dalam hal ini yang paling menonjol adalah etnis Cina. Mengapa perdagangan perantara didominasi etnis Cina? Kalau kita lihat pada kenyataannya orang Indonesia umumnya khususnya orang Jawa itu sangat sedikit yang memiliki jiwa dagang. Kebanyakan dari mereka adalah petani yang kebutuhannya tidak seberapa besar itu dicukupinya sejauh mungkin dengan usaha sendiri sehingga hampir-hampir tidak berkembang suatu golongan pedagang. ${ }^{57}$

Pedagang-pedagang Cina selain menjadi penyalur barang-barang yang diimpor oleh perusahaan Belanda, mereka juga mengimpor barang-barang kerajinan dari Siam. Impor beras dari Siam dan barang-barang kerajinan dari Cina terutama dilakukan oleh pedagangpedagang besar yang membuka beberapa

\footnotetext{
${ }^{56}$ www.kitlv.nldiakses pada : 26 Desember 2014. 57،Apakah Indonesia tjakap menjadi pedagang?"Peroendingan, 25 November 1936, h. 10.
} 
cabang di luar negeri. Barang-barang yang diimpor kemudian disalurkan kepada masyarakat melalui agen penyalur perusahaan mereka sendiri atau melalui langganan tetap mereka.

Faktor-faktor yang menunjang keberhasilan pedagang etnis Cina ialah; pertama, tumbuhnya mobilitas idealisme dalam bentuk untuk mencapai taraf kehidupan yang lebih baik daripada yang mereka peroleh selama ini. Kedua, untuk menjawab tantangan itu, ajaran itu, ajaran Konfusianisme memberikan saluran guna merumuskan pandanganpandangannya tentang dunia sebab pada dasarnya ajaran Konfusianisme lebih banyak mengatur hubungan horizontal dan memberikan landasan moral bagi lembaga horizontal tersebut. Ketiga, pandangan tentang dunia tersebut ternyata meberikan peluang bagi munculnya etos kerja seperti keuletan mereka dalam berusaha, rajin, tekun dan giat bekerja. Keempat, adanya modal yang cukup dan juga disebabkan karena faktor-faktor lain yang berasal dari pihak pribumi dan pemerintah Hindia Belanda. Dari pihak pribumi misalnya saja kurangnya modal pedagang pribumi sehingga mereka sukar bersaing dengan pedagang Cina. Kelima, pedagang-pedagang Cina hanya dapat mengembangkan usahanya di daerahdaerah yang penduduknya lebih condong untuk bercocok tanam. Keenam, faktor dari pemerintah Hindia Belanda antara lain adalah memberi kedudukan lebih tinggi kepada golongan non pribumi (Cina) daripada golongan pribumi. ${ }^{58}$

Pengaruh dalam masyarakat Indonesia, bagaimanapun pedagangpedagang Cina itu beroperasi dalam

\footnotetext{
${ }^{58}$ Seminar Sejarah Nasional IV, Sub Tema Dinamika Pertumbuhan Ekonomi Bangsa Indonesia. (Jakarta: DEPDIKBUD Direktorat Sejarah dan Nilai Tradisional, 1991), h. 207.
}

segala sendi kehidupan di Indonesia. Pengaruh tersebut dapat ditelusuri melalui kebijakan ekonomi dan politik pemerintah Hindia Belanda dan kemudian memusatkan perhatian terhadap akibat-akibat yang ditimbulkannya. Kebijakan ekonomi pemerintah Hindia Belanda di satu pihak mendukung masuknya modal-modal swasta Belanda di bidang perkebunan, pertambangan, transportasi, industri, sedangkan dipihak lain menjadikan pedagang-pedagang etnis Cina sebagai sarana untuk melakukan penetrasi ke dalam masyarakat Indonesia.

Penetrasi dengan memakai pedagang golongan etnis Cina itu tampaknya bertujuan untuk melumpuhkan basis perekonomian sabagai sarana mobilitas vertikal dari masyarakat Indonesia terutama di Jawa. Perdagangan sebagai basis mobilitas memungkinkan timbulnya kelas menengah yang mempunyai kesempatan untuk mengadakan pembaharuan atau perubahan sosial politik menggantikan struktur sosial yang monolistik, priyayi dan wong cilik. ${ }^{59}$ Dari kenyataan yang ditemukan kelas pedagang dari kalangan pribumi itu kebanyakan berasal dari kalangan Islam yang tersebar di sepanjang pantai Pulau Jawa. Dengan demikian pengaruh pedagang Cina itu hampir dapat dikatakan meluas ke seluruh lapisan masyarakat Indonesia, dari lapisan bawah sampai ke lapisan atas. Perbedaan ekonomi dan kultural antara kedua belah pihak nampaknya merupakan faktor yang berperan dalam melahirkan pembagian dan sentimen

\footnotetext{
${ }^{59}$ Lance Castles, Tingkah laku Agama, Politik dan Ekonomi di Jawa: Industri Rokok Kudus, h. 103. Dan lihat Seminar Sejarah Nasional IV, Sub Tema DinamikaPertumbuhan Ekonomi Bangsa Indonesia. (Jakarta: DEPDIKBUD Direktorat Sejarah dan Nilai Tradisional, 1991), h. 208209.
} 
ras, pribumi dan non pribumi.

Selain dari bisnis-bisnis yang disebutkan di atas, masyarakatArab juga merambah seni hiburan. Dari mereka menampilkan pertunjukkan seni dari negeri asalnya, yaitu Hadhramaut atau Timur Tengah. Banyak orang menyukai penampilan mereka dan menyebutnya sebagai Komedi Bangsawan. Seperti yang dikatakan oleh Alwi Shihab, karena kesenian ini awal mulanya muncul dari Istana-istana bangsawan. Seperti Istana Deli di Medan, dan Istana Siak di Riau. ${ }^{60}$

Lama-lama sandiwara ini berkembang, penontonnya selalu membludak. Shahab bersaudara terpikir juga untuk mengembangkan bisnis di Batavia. Mereka membangun pertokoan di sepanjang jalan menuju teater. Bahkan mereka membuka bioskop di gedung yang sama pada 1930-an. Ini bisnis baru bagi keturunan Arab di Batavia. Mereka mendobrak dominasi pengusaha Tionghoa.Bioskop itu namanya Alhambra, yang didirikan oleh tiga orang bersaudara dari keluarga Shahab: Sayid Idrus, Sayid Syehan, dan Sayid Abubakar. Bioskop itu hampir seluruhnya memutar film-film dari Mesir. Berbeda dengan bioskop lain yang sering memutar film Tiongkok dan Barat. $^{61}$

Urusan impor film bukan masalah besar, Shahab bersaudara punya jaringan sampai ke Mesir. Film-film itu ternyata memikat warga Betawi, yang datang berkelompok dari pelosok kota dengan menyewa oplet. Mudrik mengatakan, bioskop ini kelas rakyat, banderol tiketnya tidak terlalu mahal: 3 rupiah untuk duduk di kelas satu; 1,5 rupiah untuk kelas dua; dan setengah rupiah

\footnotetext{
${ }^{60}$ Alwi Shahab, Betawi Queen of The East, (Jakarta: Republika, 2002), h. 143-145.

${ }^{61}$ Hanggoro, "Berbisnis di Rantau”, h. 44-45.
}

untuk kelas tiga. Walaupun begitu Alhambra mengisi pundi-pundi Shahab bersaudara. ${ }^{62}$

Akan tetapi revolusi Mesir pada 1952 mengubah kisah manis itu, suplai film untuk Alhambra terhenti. Alhambra terpaksa memutar film Barat, seperti bioskop lainnya, tak ada keistimewaan lagi. Penontonnya pun berangsur surut, akhirnya bioskop ini tutup pada 1960-an dan gedungnya pun di jual.

Penutupan itu tak berpengaruh besar pada Shahab bersaudara, bisnis hiburan ini cuma sampingan bagi mereka. Satu bangkrut masih ada yang lainnya, ini jamak terjadi pada keturunan Arab di Indonesia. Mereka punya usaha di pelbagai lini: rente, toko, lahan perumahan, tekstil, sampai dagang kuda.

Tabel berikut ini menerangkan statistik rincian dari jumah orang Arab kaya di Nusantara dan perkiraan pendapatan mereka: ${ }^{63}$

\begin{tabular}{|l|l|l|l|}
\hline \multirow{3}{*}{ Keresidenan } & \multicolumn{3}{|l|}{ Orang Arab yang setahun berpendapatan } \\
\cline { 2 - 4 } & $\begin{array}{l}600 \mathrm{~s} / \mathrm{d} 3600 \\
\mathrm{gl}\end{array}$ & $\begin{array}{l}3600 \mathrm{~s} / \mathrm{d} \text { 12000 } \\
\text { gl }\end{array}$ & $\begin{array}{l}\text { Lebih } \\
12000 \mathrm{gl}\end{array}$ \\
\hline Banten & 1 & - & - \\
\hline Batavia & 60 & 6 & 4 \\
\hline Priangan & 5 & - & - \\
\hline Krawang & 2 & - & - \\
\hline Cirebon & 64 & 4 & - \\
\hline Tegal & 8 & 2 & 1 \\
\hline Pekalongan & 18 & 2 & 2 \\
\hline Semarang & 11 & 7 & - \\
\hline Jepara & 2 & - & - \\
\hline Rembang & 6 & - & - \\
\hline Surabaya & 79 & 6 & 5 \\
\hline Madura & 25 & 7 & 1 \\
\hline Pasuruan & 24 & - & - \\
\hline Probolinggo & 11 & 1 & - \\
\hline Besuki & 24 & 2 & - \\
\hline Kedu & 1 & - & - \\
\hline JUMLAH & 341 & 37 & 13 \\
\hline
\end{tabular}

\footnotetext{
${ }^{62}$ Hanggoro, "Berbisnis di Rantau", h. 44-45.

${ }^{63}$ Van den Berg,Orang Arab di Nusantara,h. 139.
} 


\section{Penutup}

Kondisi perekonomian saat itu di Batavia menjadi pusat kegiatan perekonomian pemerintah kolonial dengan masyarakat jajahannya yang heterogen. Masyarakat Arab di sini berperan sebagai pedagang perantara (peddler) yang menghubungkan antara masyarakat pribumi, masyarakat Cina, dan masyarakat Eropa yang ada di Batavia. Kebanyakan dari mereka menjadikan barang-barang seperti kain, khususnya katun impor, batik dan pakaian sebagai mata dagangan yang utama. Selain itu pula, produk lainnya adalah mebel, batu mulia, minyak wangi, barang-barang dari kulit, dan makanan merupakan komoditas populer yang mereka perdagangkan. Pada perkembangannya masyarakat Arab juga banyak terlibat dalam bisnis properti dan lahan atau tanah. Kegiatan lainnya di luar berdagang mereka seringkali meminjamkan uang kepada masyarakat pribumi yang ekonominya di bawah mereka dengan disertai bunga yang tinggi. Hal seperti ini bahkan mereka jadikan sebagai pekerjaan sampingan di luar berdagang. Bagi para pembeli yang tidak dapat membayar secara tunai, mereka memberikan peluang untuk menjual barang dengan sistem utang.

Pola sosial seperti ini memberikan gambaran tentang adanya harmonisasi antara masyarakat Arab dengan masyarakat pribumi bahkan dengan masyarakat lainnya. Sekalipun ada intrik yang terjadi di antara mereka, hal itu tidak menjadi sebuah permasalahan sosial yang muncul ke permukaan seperti gerakan protes dan sebagainya karena di antara mereka saling membutuhkan satu dengan yang lainnya.

Untuk itu dinamika sosial ekonomi masyarakat Arab di Batavia tahun 1900
- 1942 sangat berpengaruh terhadap denyut perekonomian masyarakat di sana. Interaksi sosial merupakan hubungan dinamis antar orang, kelompok, maupun antar orang terhadap kelompok. Syarat mutlak terjadinya interaksi sosial adalah adanya kontak dan komunikasi di antara manusia yang menimbulkan jaringan sosial.

\section{Daftar Pustaka}

\section{Sumber Primer :}

\section{Arsip}

ANRI. Pelgrimregister dalam ArsipAlgemene Secretaries: Missive Gouvernement Secretaries (MGS): Seri Grote Bundel (GB), 18921942. No. 2811 MGS 4-11-1893. GB.Ag. 2280

.Circulaire De $1^{\text {st }}$ Gouvernements Secretaris, tertanggal 23 Agustus 1910 No. 1934, Batavia: Landsrukkerij, 1911.

.Circulaire De $1^{\text {st }}$ Gouvernements Secretaris, tertanggal 16 Mei 1911 No. 1172, Batavia: Landsrukkerij, 1912.

.Circulaire De $1^{\text {st }}$ Gouvernements Secretaris, tertanggal 1 Agustus 1921 No. 89/175, Batavia: Landsrukkerij, 1922.

\section{Sumber Sekunder :}

\section{Buku-Buku}

Abdullah, Taufik \& Lapian, A.B (ed). Kolonialisasi dan Perlawanan Indonesia dalam Arus Sejarah, Jilid IV. Jakarta: PT. Ichtiar Baru van Hoeve dan Kementrian Pendidikan dan Kebudayaan RI, 2012.

Abdurrahman, Dudung. Metode Penelitian Sejarah. Jakarta: Logos Wa- 
cana Ilmu, 1999.

Abeyasekere, Susan.(ed);FromBataviatoJakarta:Indonesia 's Capital1930sto1980s, Australia: Monash University, 1985.

Al-Gadri, Hamid. C. Snouck Hurgronje, Politik Belanda terhadap Islam dan Keturunan Arab. Jakarta: Sinar Harapan, 1983.

. Islam dan Keturunan Arab di Indonesia, Jakarta: CV. Haji Masagung, 1988.

Al-Haddad, Al-Habib Alwi bin Thahir. Al-Madkhal ila Tarikh Dukhul Al-Islam Ila Jaza'ir al-Syarq al-Aqsha, karya Al-Habib Alwi bin Thahir Al-Haddad, Sejarah Masuknya Islam di Timur Jauh. Diterjemahkan; S. Dhiya Shahab, Jakarta: Lentera Basritama, 1997.

Assegaf, M. Hasyim. Derita Putri-Putri Nabi Studi Historis Kafa'ah Syarifah, Bandung: PT. Remaja Rosdakarya, 2000.

Assegaf, Sayyid Husein Nabil. Sejarah Silsilah dan Gelar Keturunan Nabi Muhammad SAW, Malang: Penerbit Saraz, 2000 .

Aziz, Abdul. Islam \& Masyarakat Betawi. Jakarta: Logos Wacana Ilmu, 2002.

Azra, Azyumardi.Jaringan Ulama Global dan Lokal Islam Nusantara, Bandung: Mizan, 2002.

Bahafdullah, Madjid Hasan. Dari Nabi Nuh Sampai Orang Hadramaut di Indonesia Menelusuri Asal-Usul Hadhrarim. Jakarta: Bania Publishing, 2010.

Balfaqih, Alwi Ibnu Muhammad. Asal-
Usul Alawiyyin dan Peranannya, Jakarta: PT. Lentera Basritama, 1999.

Baudet, H. dan I.J Brugmans, Politik Etis dan Revolusi Kemerdekaan. (Judul Asli: Balans van Beleid, Terugblik op de Laatste halve eeuw van Netherlands-Indie, Van Gorcum \& Comp. N.V. -Dr.H.J. Prakke \& H.M.G. Prakke, Assen, 1961). Diterjemahkan; Amir Sutaarga, Jakarta: Yayasan Obor Indonesia, 1987.

Berg, L.W.C. van den.Orang Arab di Nusantara, (Judul Asli: Le Hadhramout et les Colonies Arabes Dans l'Archipel Indien, Impr. du Gouvernement, Harvard University, 1886). Diterjemahkan; Rahayu Hidayat, (Ed. Terj. Bahasa Indonesia diterbitkan oleh Indonesian Netherlands Cooperation in Islamic Studies (INIS), 1989. Jakarta: Komunitas Bambu, 2010.

Blackburn, Susan. Jakarta: Sejarah 400 Tahun. (Judul Asli: Susan Abeyasekere, Jakarta; A Histo$r y$. Revised Edition. Singapore: Oxford University Press, 1989). Diterjemahkan; Gatot Triwira, Jakarta:Masup Jakarta (Komunitas Bambu), 2011.

Blusse, Leonard. Persekutuan Aneh: Pemukim Cina, Wanita Peranakan, dan Belanda di Batavia VOC. Yogyakarta: LKiS, 2004.

Boxer, C.E. Jan Kompeni dalam Perang dan Damai 1602-1799: Sebuah Sejarah singkat tentang Persekutuan Dagang Hindia Belanda. Jakarta: Sinar Harapan, 1983.

Budiman, Amen. Masyarakat Islam 
Tionghoa di Indonesia, Semarang: Tanjung Sari, 1979.

Creutzberg, Pieter dan J.T.M. van Laanen, Sejarah Statistik Ekonomi Indonesia, Terjemahan; Kustiniyati Mochtar, dkk. Jakarta: Yayasan Obor Indonesia, 1987.

Departemen Pendidikan dan Kebudayaan, Direktorat Jenderal Kebudayaan, Direktorat Sejarah dan Nilai Tradisional. Sunda Kelapa Sebagai Bandar Jalur Sutra (Kumpulan Makalah Diskusi). Jakarta: Proyek Inventarisasi dan Dokumentasi Sejarah Nasional, 1995.

Federspiel, Howard M. Sultans, Shamans and Saints; Islam and Muslim in Southeast Asia. Honolulu: University Of Hawai'i Press, 2007.

Furnivall, J.S Edisi Indonesia: Hindia Belanda: Studi tentang Ekonomi Majemuk. (Judul Asli: Netherlands India; A Study of Plural Economy. Cambridge University Press,1939). Diterjemahkan; Samsudin Berlian. Jakarta: Freedom Institute, 2009.

Giok Siong, Giow. Suatu Pengantar Hukum Antar Golongan, Jakarta, 1960.

Haan, F. De. Oud Batavia: gedenkboek uitgegeven door het Bataviaasch Genootschap van Kunsten en Wetenschappen naar aanleiding van het driehonderd-jarig bestaan der stad in 1919, Jilid I. Batavia: Kolf. 3 Jilid, 1922.

Ingleson, John. Tangan dan Kaki Terikat Dinamika Buruh, Sarekat Buruh dan Perkotaan Masa Kolonial.
Diterjemahkan; Iskandar P. Nugraha Jakarta: Komunitas Bambu, 2004.

\section{Perkotaan, Masalah}

Sosial \& Perburuhan di Jawa Masa Kolonial, Terjemahan; Iskandar P. Nugraha, Jakarta: Komunitas Bambu, 2013.

Jonge, Hubb de and Kaptein, Nico. "Trancending Borders Arabs, politics, trade and Islam in Southeast Asia". Leiden: KITLV Press, 2002.

Kartodirdjo, Sartono dan Suryo,Djoko. Sejarah Perkebunan di Indonesia: Kajian Sosial-Ekonomi, Yogyakarta: Aditya Media, 1991.

Lapian, Adrian. B. Pelayaran dan Perniagaan Abad ke-16 dan 17. Jakarta: Komunitas Bambu, 2008.

Leirissa, R. Z. Terwujudnya Suatu Gagasan Sejarah Masyarakat Indonesia 1900-1950. Jakarta: CV. Akademika Pressindo, 1985.

Leur, J.C. van. Indonesian Trade And Society; Essays in Social and Economic History. Diterjemahkan: J.S. Holmes dan R. Van Marie. Bandung: The Hauge/Bandung: Van Hoeve, 1960.

Lieng Gie, The. Sedjarah Pemerintahan Kotapradja Djakarta. Kotapradja Djakarta Raja, 1958.

Linblad, J. Thomas. Sejarah Ekonomi Modern Indonesia: Berbagai Tantangan Baru. (Judul Asli: New Challenges in the Modern Economic History of Indonesia; Proceedings of the First Conference on Indonesia's Modern Economic History, 1991). Diterjemahkan; M. Arief Rohman, Bambang Pur- 
wanto, Jakarta: Pustaka LP3ES, 2000 .

Lohanda, Mona. The Kapitan Cina of Batavia 1837-1942 a History of Chinese Establishment in Colonial Society. Jakarta: Djambatan, 2001. . Sejarah Para Pembesar Mengatur Batavia. Jakarta: Masup Jakarta, 2007.

Lombard, Denys. Nusa Jawa: Silang Budaya Kajian Sejarah Terpadu Bagian II: Jaringan Asia. (Judul Asli: Le Carrefour Javanais Essai d'histoire globale Il Les reseaux asiatiques, Paris: 1990). Diterjemahkan; Winarsih Partaningrat, Rahayu S. Hidayat dan Nini Hidayati Yusuf, Jakarta: PT. Gramedia Pustaka Utama, 2008.

Mobini Kheseh, Natalie. Hadrami Awakening, Kebangkitan Hadrami di Indonesia, Terjemahan; Ita Mutiara dan Andri, Penerbit: Akbar Media Eka Sarana, 2007.

Nas, P.J.M \& K. Grijns. Jakarta Batavia: Esai Kultural; (Judul Asli : Jakarta Batavia: socio-cultural essays. Diterjemahkan; Gita Wiya Laksmini dan Noor Cholis. Banana KITLV, Jakarta), Jakarta: Batavia, 2007.

Noer, Deliar. Gerakan Modern Islam di Indonesia 1900-1942 (Judul Asli: The Modernist Muslim Movement in Indonesia 1900-1942). Diterjemahkan; Deliar Noer.Jakarta: LP3ES, cet. kelima; 1990.

Pijper, G.F.Beberapa Studi tentang Sejarah Islam di Indonesia 1900-1950, (Judul Asli: Studien over de Geschiedenis van de Islam in Indonesia 1900-1950). Diterjemahkan;
Tudjimah dan Yessy Augustin, Jakarta: UI-Press, 1985.

Poesponegoro, Marwati Djoened. Sejarah Nasional Indonesia III, Jakarta: Balai Pustaka, 1993.

Sejarah Nasional Indonesia IV, Jakarta: Balai Pustaka, 1993.

Raffles, Thomas Stamford. The History of Java. Diterjemahkan; Eko Prasetyanigrum, Maryati Agustin dan Idda Qoryati Mahbubah. Yogyakarta: Penerbit Narasi, 2008.

Reid, Anthony. Dari Ekspansi Hingga Krisis II, Jaringan Perdagangan Global Asia Tenggara, Jakarta: Yayasan Obor Indonesia, 1999.

, Asia Tenggara Dalam Kurun Niaga 1450-1680: Jilid I; Negeri Di Bawah Angin. Jakarta: Yayasan Obor Indonesia, 2011. , Asia Tenggara Dalam Kurun Niaga 1450-1680: Jilid II; Jaringan Perdagangan Global. Jakarta: Yayasan Obor Indonesia, 2011.

Resink, G.J. Bukan 350 Tahun di Jajah. (Judul Asli: Indonesian History Between the Myths: Essays in Legal History and Historical Theory. (Vancouver: University of British Columbia, 1968). Diterjemahkan; Tim Komunitas Bambu, Jakarta: Komunitas Bambu, 2013.

Ricklefs, M.C. Mystic Synthesis in Java: A History of Islamization from the Fourteenth to the Early Nineteenth Century. Norwalk: East Bridge, 2006.

Sejarah Indonesia Modern 12002004. Jakarta: PT Serambi Ilmu 
Semesta, 2008.

Scheltema, A.M.P.A. Bagi Hasil di Hindia Belanda. (Judul Asli: Deelbouw in Nederlandsch-Indie, 1931). Diterjemahkan; Marwan. Jakarta: Yayasan Obor Indonesia, 1985.

Steenbrink, Karel A., Beberapa Aspek Tentang Islam di Indonesia Abad Ke-19. Jakarta: Bulan Bintang, 1984.

Suminto, H. Aqib. Politik Islam Hindia Belanda: Het Kantoor voor Inlandsche Zaken. Jakarta: LP3ES, 1985.

Surjomihardjo, Abdurrachman. Perkembangan Kota Djakarta; Djakarta Raja: Dinas Museum dan Sedjarah DCI, 1970.

Taylor, Jean Gelman. Kehidupan Sosial di Batavia (Orang Eropa dan Eurasia di Hindia Timur). (Judul Asli: The Social World of Batavia). Diterjemahkan; Tim Komunitas Bambu, Jakarta: Masup Jakarta (Komunitas Bambu), 2009.

Tjandrasasmita, Uka dan Tim Penyusun. Sejarah Perkembangan Kota Jakarta. Pemerintah DKI Jakarta: Dinas Museum dan Pemugaran, 2000.

, Arkeologi Islam Nusantara. Jakarta:Kepustakaan Populer Gramedia, 2009.

Vlekke, Bernard H.M. Nusantara Sejarah Indonesia. (Judul Asli: $\mathrm{Nu}$ santara: A History of Indonesia). Diterjemahkan; Samsudin Berlian, Jakarta: Kepustakaan Populer Gramedia, 2008.

\section{Disertasi :}

Affandi, Bisri. "Shaykh Ahmad Al-Surkarti: Pemikiran Pembaharuan dan Pemurnian Islam dalam Masyarakat Arab Hadrami di Indonesia." Disertasi Doktor, Institut Agama Islam Negeri Sunan Kalijaga, 1991.

\section{Skripsi :}

Shahab, Yasmin Zacky, Masalah Integrasi Minoritas Arab di Jakarta. Depok: Fakultas SastraUI, 1975.

Wibowo, Agung, Gaya Hidup Masyarakat Eropa di Batavia Pada Masa Depresi Ekonomi (1930-1939). Depok: FIB-UI, 2012.

\section{Majalah Kontemporer :}

Historia, Nomor 15. Tahun II, 2013.

Jurnal :

Jahroni, Jajang. "Menjadi Pribumi di Negeri Orang: Pergumulan Identitas Masyarakat Arab di Indonesia". Studia Islamika, Indonesian Journal for Islamic Studies, Vol. 7, No. 3, Th. 2000. h. 163-189.

Jonge, Huub de, "The Arab Minority", dalam Peter Post et al. (ed.), The Encyclopedia of Indonesia in the Pasific War. Leiden/ Boston: E.J. Brill, 2010, h. 346.

\section{Website/Internet :}

http://djawatempodoeloe.multiply.com

http://www.gahetna.nl/

www.historia.co.id

http://www.jakarta.go.id/web/ encyclopedia/detail/451/batavia 
http://www.jakarta.go.id/web/

encyclopedia/detail/755/arab

http://www.kependudukancapil.go.id

www.moranmicropublications.nl

http://phesolo.wordpress.com

http://tempodoeloe.wordpress.com

(Footnotes)

${ }^{1}$ Van den Berg,Orang Arab di Nusantara,h. 139. 
Akhmad Yusuf :

Dinamika Ekonomi Masyarakat Arab ... 